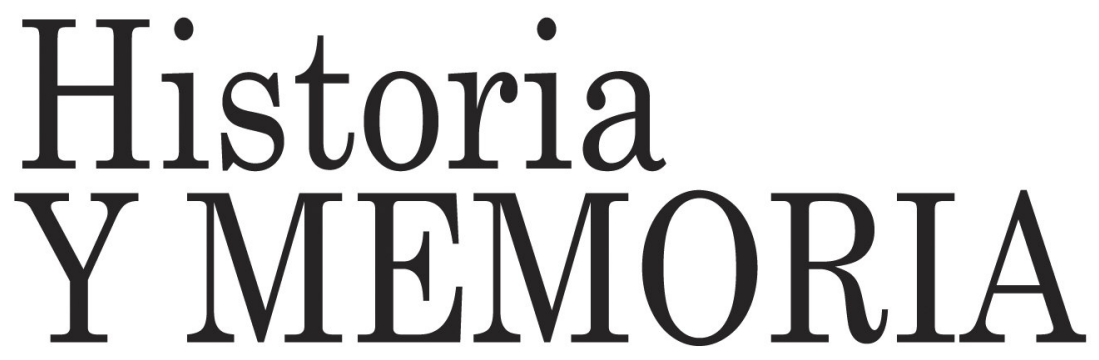

ISSN: 2027-5137

Julio - Diciembre, Año 2013 - Tunja, Colombia

La Asimilación Mexicana: Colombia en los años treinta. E1 caso de Ignacio Gómez Jaramillo

Juanita Solano Roa Páginas: 79 - 111

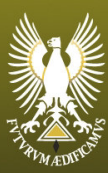




\title{
The Mexican Assimilation: Colombia in the 1930s - The case of Ignacio Gómez Jaramillo
}

\author{
Juanita Solano Roa ${ }^{1}$ \\ Institute of Fine Arts, New York-Estados Unidos
}

Recepción: 09/09/2013

Evaluación: 09/09/2013

Aceptación: 05/10/2013

Artículo de Investigación Científica.

\section{Abstract}

During the 1930s in Colombia, artists such as Ignacio Gómez Jaramillo, took Mexican muralism as an important part of their careers thus engaging with public art for the first time in the country. In 1936, Gómez Jaramillo travelled to Mexico for two years in order to study muralism, to learn the fresco technique and to transmit the Mexican experience of the open-air-schools. Gómez Jaramillo returned to Colombia in 1938 and in 1939 painted the murals of the National Capitol. Although Gómez Jaramillo's work after 1939 is well known, his time in Mexico has been barely studied and very few scholars have analyzed the artist's work in light of his Mexican experience. While in Mexico, Gómez Jaramillo joined the LEAR (La Liga de Escritores y Artistas Revolucionarios) with whom he crated the murals of the Centro Escolar

\footnotetext{
${ }^{1}$ Licenciada en Artes, Universidad de los Andes-Colombia. Maestra y candidata a doctora en Artes, Institute of Fine Arts, New York. Tesorera de la Red de Estudios Visuales Latinoamericanos. Líneas de investigación: Historia de la fotografía en Latinoamérica. http://revlat.blogspot.com/. juanitasolano@gmail.com.
} 
Revolución. These murals depict politically engaged images that, apparently, little had to do with his more historical work back in Colombia. This text proposes a careful reading of the artist's work at the CER and a rereading of the National Capitol murals in light of a more politicized vision.

Keywords: Muralism, Ignacio Gómez Jaramillo, Centro Escolar Revolución, Liga de Escritores y Artistas Revolucionarios, National Capitol.

\section{La Asimilación Mexicana: Colombia en los años treinta - El caso de Ignacio Gómez Jaramillo}

\section{Resumen}

Durante la década de los treinta, artistas como Ignacio Gómez Jaramillo tomaron el muralismo mexicano como una parte importante de sus carreras y así mismo adoptaron la iniciativa de realizar por primera vez en Colombia arte público. En 1936 Gómez Jaramillo viajó a México durante dos años con el fin de estudiar el muralismo, aprender la técnica del fresco y transmitir la experiencia mexicana de las escuelas de pintura al aire libre. Gómez Jaramillo regresó a Colombia en 1938 y en 1939 pintó los murales del Capitolio Nacional. Aunque el trabajo de Gómez Jaramillo después de su regreso a Colombia es bien conocido, su tiempo en México ha sido escasamente explorado y pocos historiadores han analizado el trabajo del artista a la luz de su experiencia mexicana. Durante su estadía en México, Gómez Jaramillo se incorporó al grupo de la LEAR (La Liga de Escritores y Artistas Revolucionarios) con la cual creó los murales en el Centro Escolar Revolución (CER). Estos murales son imágenes políticamente comprometidas que aparentemente poco tendrían que ver con su trabajo más 
The Mexican Assimilation: Colombia in the 1930s - The case of Ignacio Gómez Jaramillo

histórico a su regreso a Colombia. Este texto propone una revisión cuidadosa al trabajo del artista en el CER y una relectura de los murales del Capitolio Nacional a la luz de una visión más politizada.

Palabras clave: Muralismo, Ignacio Gómez Jaramillo, Centro Escolar Revolución, Liga de Escritores y Artistas Revolucionarios (LEAR), Capitolio Nacional.

\section{L'assimilation mexicaine: Colombie dans les années 1930 - Le cas d'Ignacio Gómez Jaramillo}

\section{Résumé}

Pendant les années trente, certains artistes tel que Ignacio Gómez Jaramillo ont envisagé le muralisme mexicain comme une partie importante de leurs carrières et ont entrepris, pour la première fois en Colombie, la production d'un art public. En 1936 Gómez Jaramillo s'est rendu au Mexique pendant deux ans afin d'étudier le muralisme, s'imprégner de la technique de la fresque, et connaître l'expérience mexicaine des écoles de peinture en plein air. Gómez Jaramillo est retourné en Colombie en 1938, et l'année suivante il peint des fresques au Congrès national. Bien que le travail de Gómez Jaramillo après son retour en Colombie est bien connu, le temps qu'il a passé au Mexique a été faiblement exploré et peu d'historiens ont analysé le travail de l'artiste à la lumière de son expérience mexicaine. Durant son séjour au Mexique, Gómez Jaramillo s'est incorporé au groupe LEAR (Ligue d'Écrivains et d'Artistes Révolutionnaires) avec lequel il a créé les fresques au Centre Educatif Révolution (CER). Ces fresques sont des images politiquement engagées qui, apparemment, ont peu à voir avec le travail plus historique qu'il a entrepris à son retour en Colombie. Ce 
texte propose une révision soigneuse de l'œuvre accomplie par l'artiste dans le CER, de même qu'une relecture des fresques du Capitole national à la lumière d'une vision plus politisée.

Mots clés: Muralisme, Ignacio Gómez Jaramillo, Centre Éducatif Révolution, Ligue d'Écrivains et d'Artistes Révolutionnaires (LEAR), Capitole national.

\section{1.}

The phenomenon of muralism and the implementation of public art as a means to promote political agendas and governmental interests did not limit itself to Mexico, but expanded throughout the Americas during the 1920s and 1930s. Arriving to Colombia through Universidad, ${ }^{2}$ a magazine that during its second period (1927-1929) embraced the arts as a significant topic, the Mexican movement provoked a crucial change in the understanding of the fine arts in the country, as well as a new modern attitude towards it. In the 1920s, a group of artists today remembered as Los Bachués embraced indigenism as a way of rescuing national identity and promoting the "Americanist" feeling that characterized the continent in those decades. ${ }^{3}$ However, it was with

\footnotetext{
${ }_{2}^{2}$ The first phase of the magazine took place between 1921 and 1922, while the second one from 1927 to 1929. The fine arts topic was embraced only in the second phase, thanks to the support of writer Baldomero Sanín Cano (1861-1957). It was a humble magazine that wanted to reveal new artworks with a journalistic point of view. Universidad was contemporaneous to other important Latin American magazines such as Ulises in Mexico, Amauta in Lima and Revista de Avance in Havana. See Álvaro Medina. El arte Colombiano de los años 20 y 30 (Bogotá: Colcultura, 1995),17-43.

3 Historically the first generation of artists in the 1930s in Colombia has been recognized under the name of Bachués even though they did not consider themselves a group or a movement. Among the Bachué artists are Romulo Rozo, Luis Alberto Acuña, José Domingo Rodríguez, Ramón Barba, Josefina Albarracín and Hena Rodríguez.
} 
The Mexican Assimilation: Colombia in the 1930s - The case of Ignacio Gómez Jaramillo

the advent of a new liberal government in the 1930s that public art emerged in Colombia and that muralism became an important part of its art history. The socialist values of the Mexican revolution became a guide for new ideals that Colombia's nascent government wanted to appropriate after years of social unrest and violence that emerged in the context of the last period of conservative hegemony (1880-1930). Within the liberal government, public art became a means for the dissemination of those principles, thus distanced away from communist imagery and explicit political engagement. The public art projects that took place during this decade were characterized by the support of the liberal government and, as I will demonstrate, became part of the strategies of their alliance with the socialist branches of the political sphere in the context of president Alfonso López Pumarejo's Revolución en Marcha (Ongoing Revolution).

In 1936, the government of López Pumarejo (1934-1938) supported Colombian artist Ignacio Gómez Jaramillo's two-year trip to Mexico to study the work of the muralists, learn the fresco technique, and implement his knowledge upon his return to Colombia. What exactly was behind the government interests in supporting public art? How was it appropriated and understood in Colombia? How did it become part of a political agenda without addressing politically engaged imagery? This paper will explore these questions by analyzing Ignacio Gómez Jaramillo's murals completed in the 1930s, both in Mexico and Colombia.

Born in Medellín in 1910, Ignacio Gómez Jaramillo started his studies in painting and drawing in 1924 at the Escuela de Pintura, Dibujo y Escultura at the Instituto de Bellas Artes of Medellín. At the age of seventeen he went to the Escuela de Minas, where he was approved to train for a year in engineering. His early goal was to become an architect, the reason for which he traveled to Europe in 1929. Because of his relatively poor education, however, he was not able to follow his intended path 
and decided to settle in Barcelona, committing himself to painting. While in Spain, Gómez Jaramillo painted a series of pictures that reflected his initial interest in social issues, a subject that he would never again depict in easel paintings, but which reappeared in his mural work. The best known of the series are El poeta comunista (1931; Image1) and El proletario (1932), paintings that, without their titles, would not lend themselves to any political interpretation of subject. For example, $E l$ poeta comunista depicts a three-quarter-view portrait of a young man sitting in an ambiguous context while strongly holding his left arm with his right hand. There are no signs in the painting to indicate that the sitter is either a poet, much less a communist. Gómez Jaramillo occasionally took advantage of this ambiguity renaming the painting El poeta del campo whenever he needed to avoid political conflict.

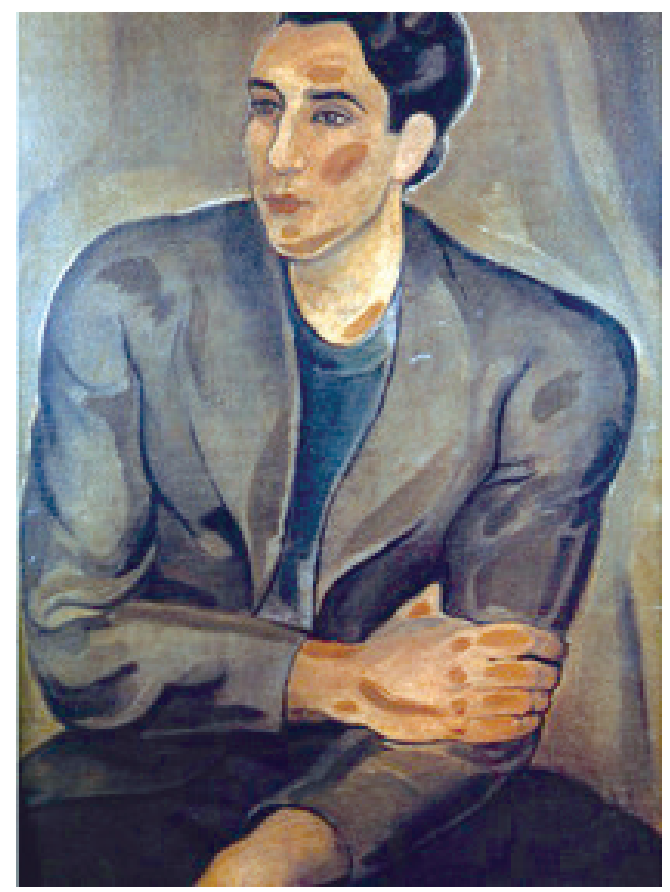

Image 1. Ignacio Gómez Jaramillo, El poeta comunista, 1931. Oil on canvas $92 \times 72.5 \mathrm{~cm}$ Image taken from the book Ignacio Gómez Jaramillo. Bogotá: Villegas Editores, 2003. 
The Mexican Assimilation: Colombia in the 1930s - The case of Ignacio Gómez Jaramillo

Gómez Jaramillo studied the painting of the European avant-garde artists closely, thus never abandoning his more classical style and interests; his easel paintings depict traditional subjects such as landscapes, portraits, still lives, and nudes, a series of subjects that he never neglected but that did not reflect in his murals, wherein the artist assumed a progressive attitude. He became especially interested in the paintings of Cézanne, as evidenced when one compares his Vista de Toledo (1930; Image 2) to Cézanne's Mont Sainte-Victoire (1892-1906; Image 3). ${ }^{4}$ Gómez Jaramillo appropriates some of Cezanne's stylistic features like the line, the geometry of the figures, and black contours. He returned to Colombia following his mother's death in 1933, and held his first exhibition in Barranquilla. The show's enormous critical success opened the door to a series of exhibitions in Bogotá and Medellín during the following years.

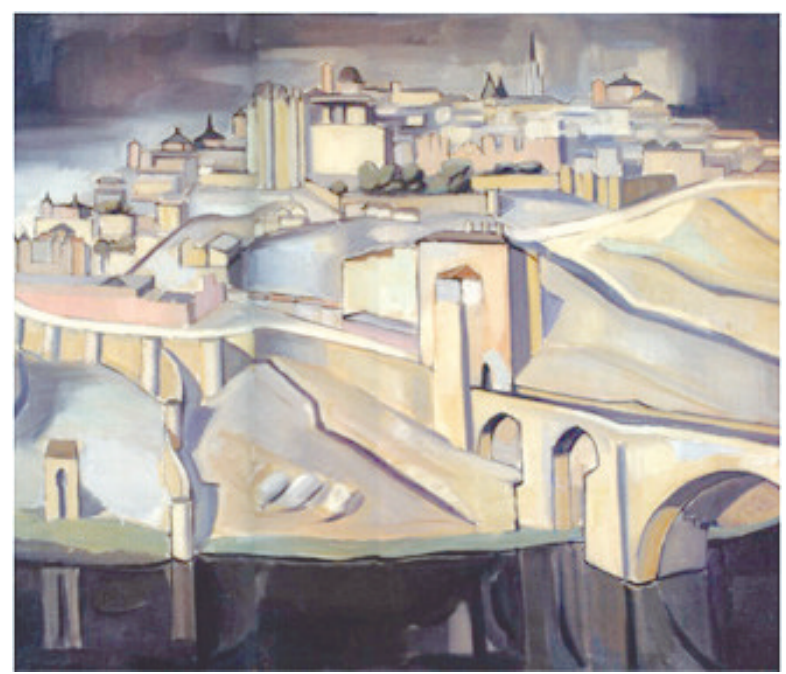

Image 2. Ignacio Gómez Jaramillo. Vista de Toledo, 1930. Oil on canvas 100 x $118 \mathrm{~cm}$. Image taken from the book Ignacio Gomez Jaramillo. Bogotá: Villegas Editores, 2003.

${ }^{4}$ Other Spanish artists such as El Greco did paintings of the same subject (Vista de Toledo, 1596-1600). Diego Rivera in 1912 depicted the same landscape in one of his early paintings (Vista de Toledo, 1912). 


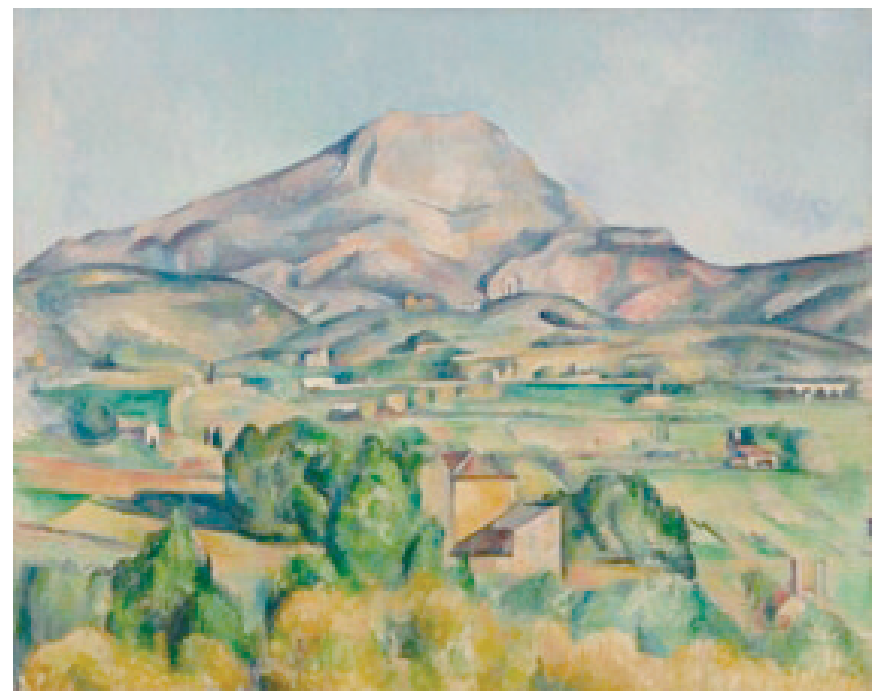

Image 3. Paul Cézanne, Mont Sainte-Victorie, 1892-1895. Oil on canvas 28 3/4 x 36 1/4 (73x92 cm.)

The 1930s in Colombia were a violent political era already evident in the preceding decade, as two major events took place at the end of the 1920s: the brutal execution of thousands of workers during the Bananeras Massacre of 1928, followed by the bloody suppression of a student movement in 1929. ${ }^{5}$ The social unrest that followed led to an imminent political change after years of conservative power, introduced by a new liberal government headed by President Enrique Olaya Herrera (1930-1934) and followed by Alfonso López Pumarejo (1934-1938). The latter's ideals followed what is today known as La Revolución en Marcha, a plan that

\footnotetext{
5 The Bananeras Massacre took place in 1928 in the Caribbean region of Santa Marta. A group of workers from the United Fruit Company started a strike against the bad working conditions they were subject to. The corporation's directors contacted high-ranged politics from the conservative government to help them stop the strike. The government sent the army, who broke in fire against the demonstrators. It has never been told how many people were killed; the official report stated that only nine persons were murdered, but later reports say that approximately 4.000 people. Gabriel García Marquez makes a memorable reference to the event in his book One Hundred Years of Solitude from 1967.
} 
The Mexican Assimilation: Colombia in the 1930s - The case of Ignacio Gómez Jaramillo

intended to create radical social changes in the country. His governmental philosophies allowed for a union between the liberal party and radical leftists using the slogan "Colombia for the Colombians," a response to the United States's resented, yet official, Monroe Doctrine of 1823, which claimed "America for the Americans." Touted as a mass social program, the Revolución was considered the running engine of the government. While in Mexico a few months after assuming the presidency, López Pumarejo declared in a public speech that the most important part of being in the country was direct contact with the revolution, assuring the expansion of its embedded values to Colombia. During his time in power several important changes took place: the construction of the Ciudad Universitaria in 1935, the expansion and diversification of the communication industries, and the construction of highways and transportation media, among others. One of the most important characteristics of his government was the promotion of education as the main basis of the revolution; it is in this context that Gómez Jaramillo's role acquires historical importance.

Minister of Education Jorge Zalamea was deeply involved in the political sphere and, as a supporter of Gómez Jaramillo's work, was determined to incorporate muralism in Colombia; he assisted the artist with attaining a grant from the government to travel to México from 1936 to 1938. As art historian Álvaro Medina has pointed out, the aims of Gómez Jaramillo's visit were to study Rivera's, Orozco's, and Siqueiros' murals, learn the fresco technique, and transmit the experience of the escuelas de pintura al aire libre (open-air painting schools). ${ }^{6}$ These goals reveal the political intentions of the Colombian government behind his support. It was evident that muralism in Mexico had become a political tool that served to transform the political understanding

\footnotetext{
${ }^{6}$ Álvaro Medina, El arte Colombiano de los años 20 y 30 . (Bogotá: Colcultura, 1995), 165.
} 
of the masses and to educate them, thus becoming the perfect device for the Colombian government's new ideals and intentions.

The interest in the escuelas was related to the educational purposes of López Pumarejo, who probably saw the project as an additional element that could be integrated to the already existent mass cultural program of the country. In Colombia, a campaign to educate the highly illiterate masses was taking place through a cultural program designed by the liberal government, which utilized diverse media like cinema, radio, and ambulant schools, the later already implemented in the country since 1931. Such schools were part of a successful system that traveled to the country's hidden towns, bringing with them literacy brigades, the promotion of a reading culture, and knowledge related to hygienic issues. $^{7}$

The Mexican escuelas, however, also intended to educate the poorest branches of society and to use artistic education in order to compensate analphabetism, but a different system was employed. Through a non-academic approach that embraced an alternative way of teaching, the escuelas promoted popular education through art that intended to "awaken the young to an appreciation of Mexican art and help[ed] them recover their national pride lost with the submission on European standards until 1911." " Alfredo Ramos Martínez directed the program that was part of a "dissenting branch from the Academia de Bellas Artes" simultaneously supported by José Vasconselos, at the time Minister of Culture and President of the University of Mexico. The results

\footnotetext{
${ }^{7}$ Renán Silva, República Liberal, intelectuales y cultura popular. (Medellín: Carreta Editores, 2005), 171-172.

8 Ana Mae Barbosa. "The Escuelas de Pintura al Aire Libre in Mexico: Freedom, Form, and Culture" in Studies in Art Education. Vol. 42, No. 4 (Summer, 2001): 287.
} 
The Mexican Assimilation: Colombia in the 1930s - The case of Ignacio Gómez Jaramillo

of the escuelas came in many different styles, most of them mainly naïve, even though important artists like Siqueiros attended the schools at the beginning of their careers.

In September 1936 Gómez Jaramillo published a report about the Mexican escuelas in the Colombian magazine Revista de las Indias. ${ }^{9}$ The document presented a critical review about the schools, which he considered a program that tried to encourage students to delve into the fine arts without imposing any new rules that would alienate them from their original sensibilities. Gómez Jaramillo believed that the escuelas promoted a non-academic formation that revealed the "vital background of el pueblo, the mestizo people" and that the methodology encouraged the children to learn painting before they learn to read or write. ${ }^{10}$ However, his report explicitly opposed the implementation of such a system in Colombia because "the schools separated the students from their original professions (shoemakers, masons, carpenters, etc) and caused them temptation to become painters thanks to the success of the exhibitions organized by the government."11 The problem, according to Gómez Jaramillo, was the enormous influx of painters that the government could not sustain, which became one of the main reasons for the system's failure. It is likely that the incorporation of the escuelas de pintura al aire libre never took place in Colombia because of this report.

While in Mexico, Gómez Jaramillo became involved with the arts and political scene. He painted two murals at the Centro Escolar Revolución (CER), titled

9 The Revista de las Indias (1936-1951) was the most important means of expression for the new group of intellectuals who were ultimately the cultural support of liberalism in the government.

${ }_{10}$ Ignacio Gómez Jaramillo, Anotaciones de un pintor (Medellín: Ediciones Autores Antioqueños, 1987), 136.

11 Ignacio Gómez Jaramillo, Anotaciones de un pintor..., 137. 
La represión de los obreros (1937; Image 4). The frescos were part of a larger commission that the Mexican government assigned to the Liga de Escritores y Artistas Revolucionarios $(L E A R)^{12}$ as part of the so-called "socialist education" program, which attempted to "implement the long delayed democratization of education promised by the Mexican Revolution."13 Six artists contributed to the project: Raúl Anguiano, Everardo Ramírez, Gonzalo de la Paz Pérez, Antonio Gutiérrez, Aurora Reyes, and Ignacio Gómez Jaramillo. As newspapers pointed out, the commission of the $C E R$ was originally intended for Diego Rivera, but because of his great amount of work he was not able to fulfill the task, transferring the assignment to a group of his students within the LEAR. ${ }^{14}$

12 The Liga de Escritores y Artistas Revolucionarios (LEAR) was founded in 1933 as the Mexican section of the International Union of Revolutionary Writers and Artists founded originally in former URSS. The communists organized the $L E A R$ in a context of re-organization of the national forces. Among the founders were Pablo O'Higgins, Luis Arenal, David Alfaro Siqueiros, Leopoldo Méndez and Juan de la Cabada. The group had a newspaper named Frente a Frente through which they intended to disseminate their ideals. The $L E A R$ claimed for the resumption of the relationships with USSR and the liberty of expression. Slowly, many artists and intellectuals from different tendencies joint the $L E A R$ in order to built organizations that fought against fascism. They believed in the power of art to awaken the political consciousness and improved society.

13 Dina Comisarenco. "Aurora Reyes's 'Ataque a la maestra rural" in Woman's Art Journal Vol. 26 No. 2 p.21

14 See "Diego Rivera decorará el Centro Revolución." El Nacional: Diario popular (Mexico City)

January 11, 1935 and "Pinturas en las escuelas." El Nacional: Diario popular (Mexico City), December 24, 1935. 


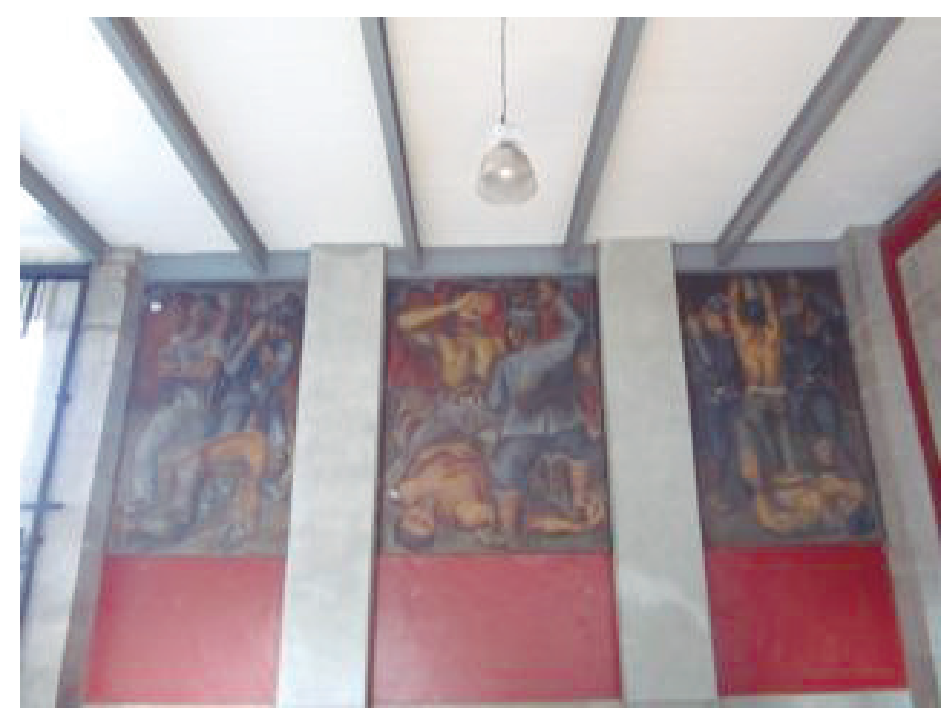

Image 4. Right and Left: Ignacio Gómez Jaramillo La represión de los obreros, 1937. Fresco, Center: Raúl Anguiano Represión porfirista, 1937 Fresco Photo: Juanita Solano.

The murals of the $C E R$, located at the foyer of the school, addressed issues related to the unique history of the building, the strong opposition against fascism and the success of socialist education and the revolution. ${ }^{15}$ Situated in front of the school's entrance, five of the panels are designed to be read from the center to the sides. The central mural, painted by De la Paz Perez, depicts a monumental building bearing the inscription Escuela Socialista. The structure's architecture symbolically evokes a hybrid between the Monumento a la Revolución in Mexico City and the Centro Escolar Revolución itself. To the sides of the building appear two hands holding the communist symbols of the hammer and sickle, and in the bottom section stands a series of objects and symbols representing war, fascism and religion. Adjacent to the central mural hang two panels painted by Anguiano in which the composition is divided into two parts. In its lower portion, the left fresco illustrates the death

15 Dina Comisarenco. "Aurora Reyes, Ataque a la maestra rural"...,21. 
of the corrupted power represented by the cleric and the military, while the upper level depicts the triumph of socialism and the establishment of a new, better world. Conversely, the mural to the right represents the iniquities of fascism with the depiction of a swastika emanating destructive rays that destroy culture and kill men. The final two murals are positioned at each of the corners, each alluding to the issue of education. On the left side, the mural by Gutiérrez shows a teacher lying on the ground surrounded by his students while a murderer with a knife is trying to escape. On the right corner stands the panel painted by Aurora Reyes-the first Mexican woman muralist-which depicts a female teacher being attacked by two men. In front of these five panels, and to each of the sides of the Centro Escolar's entrance, are three larger vertical panels. On right side hang Ramírez's and De la Paz's murals, which again illustrate the role of socialist education; to the left are the panels by Gómez Jaramillo and Anguiano (Image 5). ${ }^{16}$

Even though the murals have different namesLa represión de los obreros by Gómez Jaramillo and Represión porfirista by Anguiano-the three paintings work as a triptych and are meant to be read together. The first panel painted by Gómez Jaramillo depicts three handcuffed men and a policeman hitting one of the prisoners with a shotgun. The victim appears in the foreground of the composition, kneeling on his hands and feet and wearing only a pair of blue pants and a red belt, while the other two captives lament the violent scene that is taking place. One of them avoids direct eye contact by looking to the opposite side of the scene, while the other holds his hands in front of his face to

16 Raúl Anguiano (1915-2006) was a prolific Mexican artist identified with the second generation of Mexican muralists. Most of his work focuses on indigenous and rural life in Mexico. He was part of the LEAR and a founder of the Taller de Gráfica popular along with artists Leopoldo Méndez, Alfredo Zalco and Pablo O'Higgins. 
The Mexican Assimilation: Colombia in the 1930s - The case of Ignacio Gómez Jaramillo

cover his eyes. The incident occurs in front of a large red modern building that recalls the architecture of the Centro Escolar Revolución. The second panel, painted by Anguiano, depicts a prisoner who covers his face with one of his hands to protect himself from what seems to be the same policeman beating him with a wooden stick. In the foreground another prisoner appears lying on the ground, already defeated by the violent policeman. The background of this mural depicts a man holding a red flag whose face is not visible (Image 6). The third and final panel is painted by Gómez Jaramillo and illustrates a scene in which two policemen again torture captives. This time one of the hostages, turned on his back, hangs from a tube while the authorities are torturing him. A second prisoner is lying handcuffed on the floor (Image $7)$.

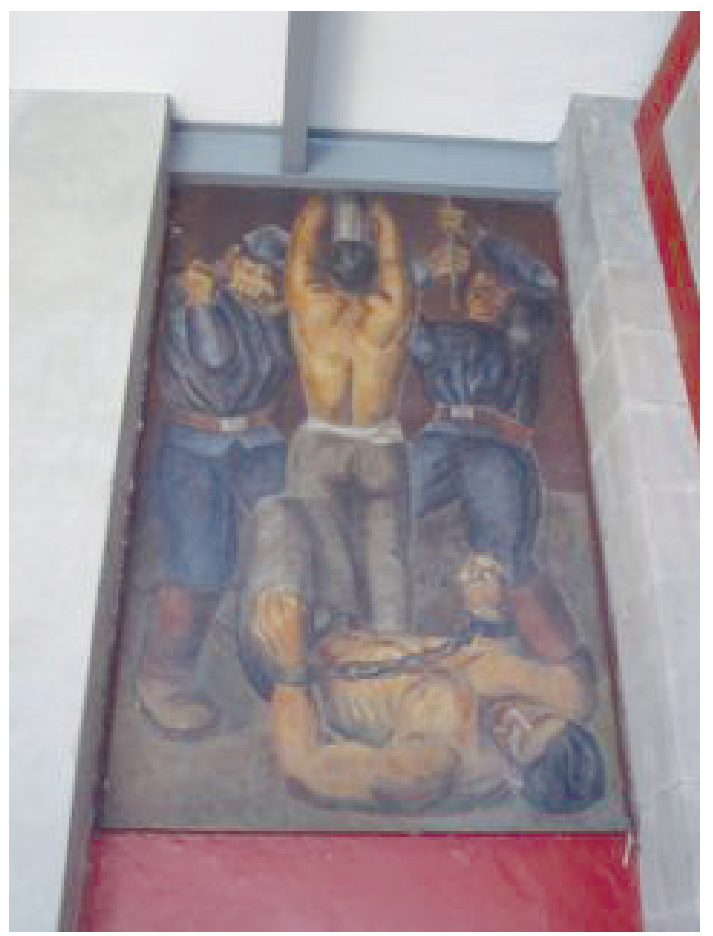

Image 5. Ignacio Gómez Jaramillo

La represión de los obreros, 1937

Fresco

Photo: Juanita Solano 


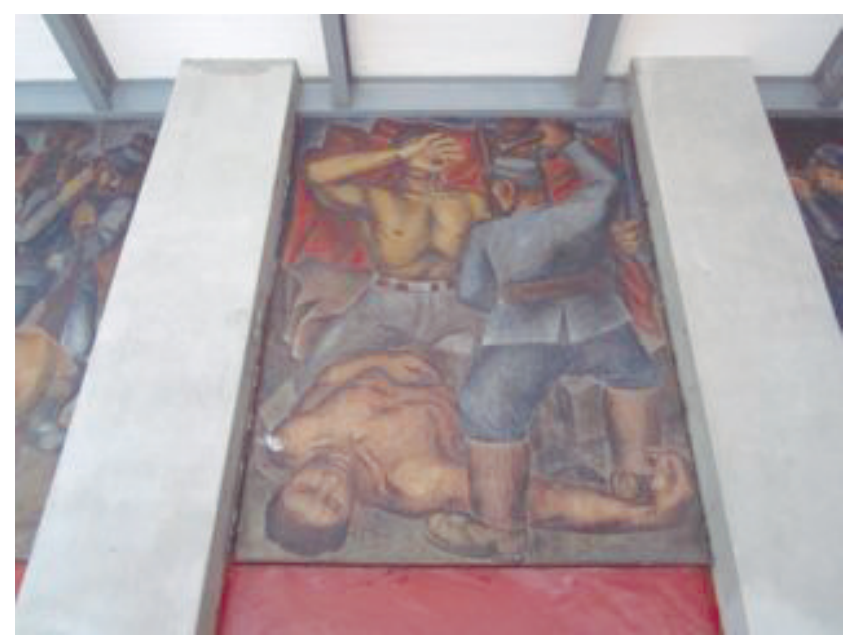

Image. 6

Raúl Anguiano

Represión porfirista, 1937

Fresco

Photo: Juanita Solano

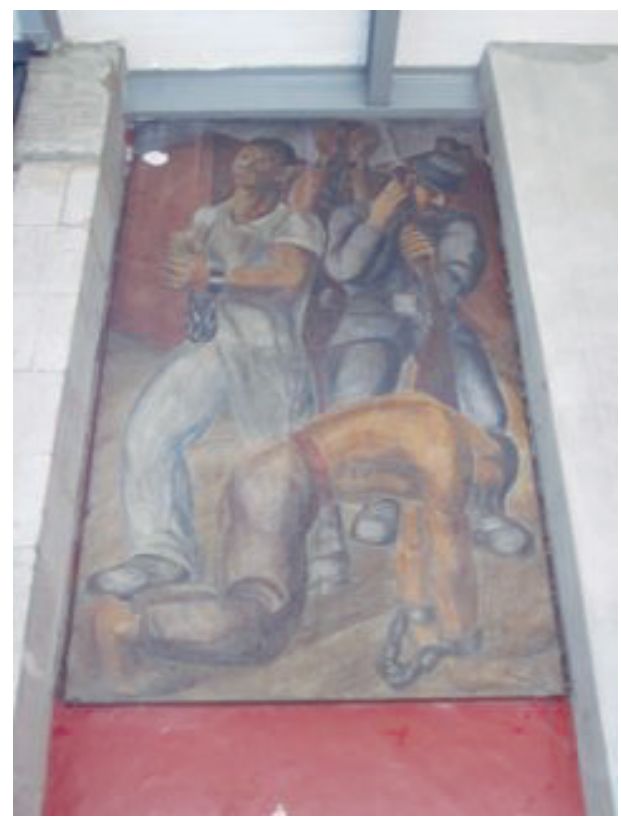

Image 7

Ignacio Gómez Jaramillo

La represión de los obreros, 1937

Fresco

Photo: Juanita Solano 
The Mexican Assimilation: Colombia in the 1930s - The case of Ignacio Gómez Jaramillo

An event that occurred close to the time of the commission of the murals, which likely inspired the depiction of captured prisoners, was the release of all political hostages by the Cárdenas government, which was one of the aims the $L E A R$ was fighting against. The subject of torture is a theme that has accompanied the history of both Mexico and Colombia from colonial times to the present, and that certainly did not escape the attention of Anguiano and Gómez Jaramillo. Although represented as muscular and strong, the lynched subjects in the murals are unable to fight against the repressive authorities tormenting them. Torture has been utilized as a war weapon that sadly affects not only those committed to the war but also the less favored social classes, who cannot avoid being involved in the violent episodes of war. The subjects depicted by Anguiano and Gómez Jaramillo are the only ones that do not address education as a central argument. As art historian Dina Comisarenco has pointed out, the triptych makes reference to the "discrimination and violence of the porfirian regimen against all political dissent" and to the particular history of the building itself. ${ }^{17}$

Before the Centro Escolar Revolución was built, many other institutions occupied its space. During colonial times, the lot held a religious retirement center for women, later becoming a school for girls. In 1863 the building was converted into a jail, the Prisión de Belén, a site remembered for the tortures that occurred in the dungeon during the dictatorship of Porfirio Díaz (18761911), which is most likely the episode that the artists were referencing. In 1933 the jail was destroyed, and the construction that today houses the Centro Escolar was built under the supervision of architect Antonio

${ }_{17}$ Dina Comisarenco. "Aurora Reyes's 'Ataque a la maestra rural”...,21 
Muñoz, who also directed the construction of El mercado Abelardo Rodríguez.

La repression porfirista and La represión de los obreros draw the viewer's attention when compared with the other murals because of the dark palette that opposes the warm colors of the rest of the cycles, especially with the triptych's correspondent murals by Ramírez and de la Paz. The use of extreme perspective, deliberately chosen by Anguiano and Gómez Jaramillo, is another device that distinguishes the panels that hang in the high portion of the wall. The dejected prisoners lying on the floor project frontally to the spectator, integrating this way the display space and the public into the murals.

There is a logical correlation between the space and the three cycles of murals. In the 1930s the CER became a milestone in the urban landscape of Mexico City because it transformed not only visually but also culturally a degraded neighborhood. The entrance of the school is partially open (it is only covered by a fence) allowing for a street view of the frontal murals, even when the school is closed. The location of Ignacio Gómez Jaramillo's frescos is deliberate in this regard since, contrary to the central panels, the murals are not visible from the outside. Perhaps the artists consented to leave the triptych in a less visible space because of the work's explicit brutality, placed alongside the frescos that uplift the triumph of socialist education.

The decorative program of the $C E R$ was part of a second phase in the construction of the building. The original plan only took into account the intervention of the architect Antonio Muñoz and artist Fermín Revueltas. During the construction and development of the school, however, the original intention was transformed and the 
The Mexican Assimilation: Colombia in the 1930s - The case of Ignacio Gómez Jaramillo

integration of the murals took place. ${ }^{18}$ A group proposal, in charge of the mural painting section of the $L E A R$, was in charge of the decoration plan. A premeditated, muted color palette and a programmatic, almost homogeneous style were used to create the murals that, as art historian Luz Angélica Beltrán points out, contrast with the monochromatic architecture of the rest of the building. ${ }^{19}$ Opposed to earlier Mexican muralism, the cycles at the $C E R$ do not illustrate any specific characters, but are instead anonymous subjects, in this way underlying the importance of the message over portraits.

Gómez Jaramillo returned to Colombia in 1938, and that same year he received the commission of a series of murals in the capital of the country. His most controversial works, La liberación de los Esclavos (1938; Image 8) and La Insurreción de los Comuneros (1938; Image 9), are located at the National Capitol in Bogotá. The first mural depicts the liberation of slaves in 1851 under the government of José Hilario López, who is shown standing in a sophisticated military uniform on the right side of the painting, signaling with his hand the liberation of the slaves. The eleven remaining figures in the mural are handcuffed, indicating their continued enslavement. Three individuals from the composition deserve particular attention. The first one is the kneeling woman with her child at the foreground of the picture, a composition that alludes to a law protecting the liberty of the slaves - the "Law on Freedom of wombs"- enacted in 1821 after Colombian independence in 1810. The law claimed that children born after that date should stay with their slave mothers until the age of eighteen, at

\footnotetext{
18 There are eight stain glass works by Revueltas in the former library of the school.

${ }^{19}$ Luz Angélica Beltrán Trenado. "Centro Escolar Revolución: la construcción de un espacio escolar" (Masters Thesis, UNAM, 2009), 29.
} 
which time they would become officially free. Only with the 1851 "Freedom Act of Slaves in Colombia", however, were all slaves in the country actually liberated. The second noteworthy figure is the man located right behind the woman, standing with his arms handcuffed and raised above his head, which recalls Gómez Jaramillo's last panel of the Centro Escolar Revolución. In the same manner, these two compositions make reference to one of David Alfaro Siqueiros's early works El Tormento from 1930, in which a half-naked prisoner, escorted by two policemen, hangs in the same position as Gómez Jaramillo's figures (Image 10). The Colombian artist was very close to Siqueiros and admired his work profoundly. He might have seen the painting during his time in Mexico, and it is highly probable that the impact of the work was striking since it alluded to the torture that many prisoners suffered under the porfiriato. The third figure that draws attention in the mural is the Indian slave on the upper left corner, who is carrying a bundle of sugar cane. This figure appropriates Rivera's depictions of the same theme, which can be found in his mural Sugar Plantation (1930) at the Palacio Cortés in Cuernavaca, as well as in the portable mural Sugar Cane made for New York's Museum of Modern Art retrospective in 1931. Gómez Jaramillo wanted to make the reference evident, which can be seen by comparing the sketch made for the mural and the mural itself. In the sketch, the Indian is partially covered by other characters, which in the final version are displaced in order to emphasize the Indian. 
The Mexican Assimilation: Colombia in the 1930s - The case of Ignacio Gómez Jaramillo

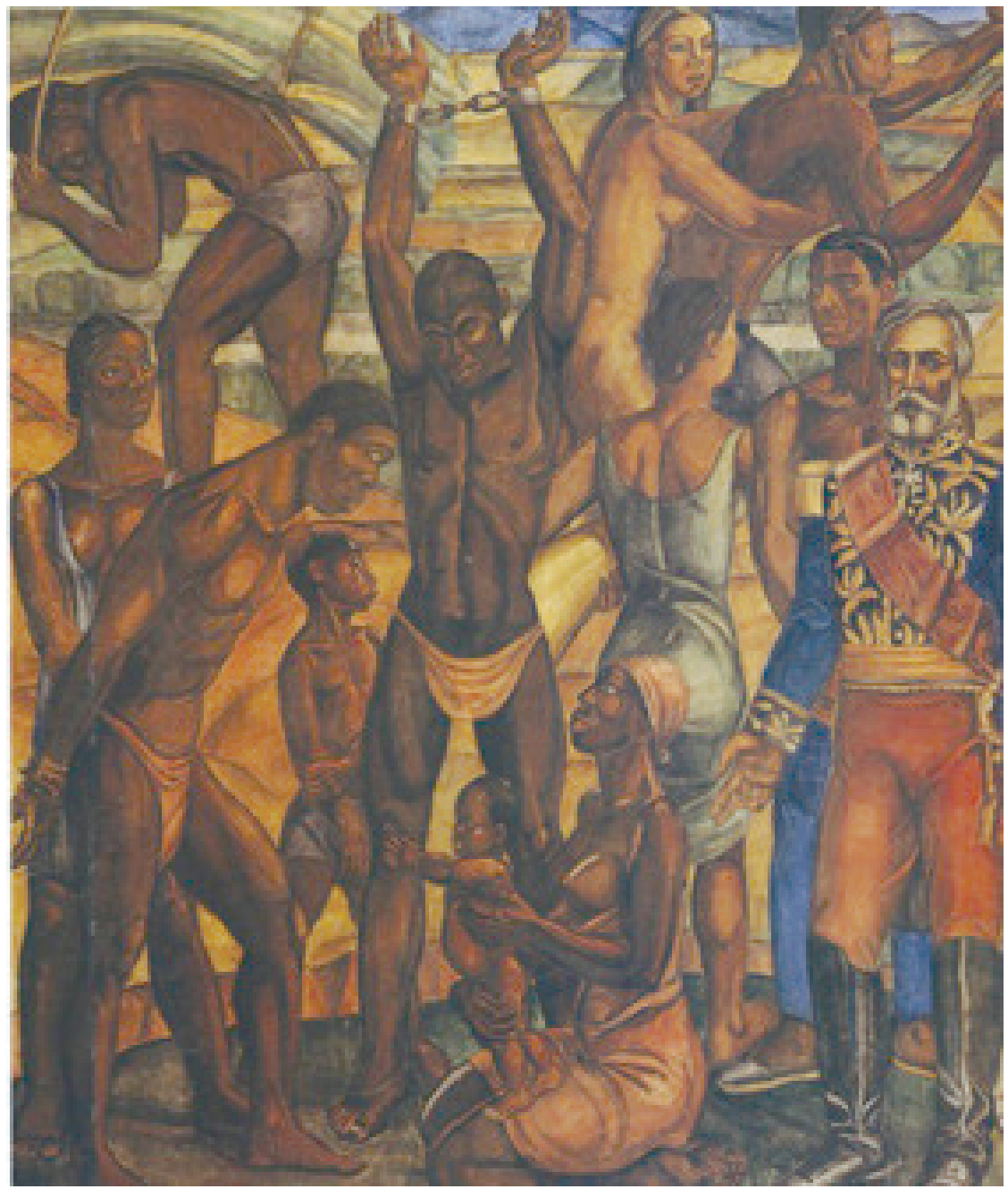

Image 8

Ignacio Gómez Jaramillo

La liberación de los esclavos, 1938

Fresco 


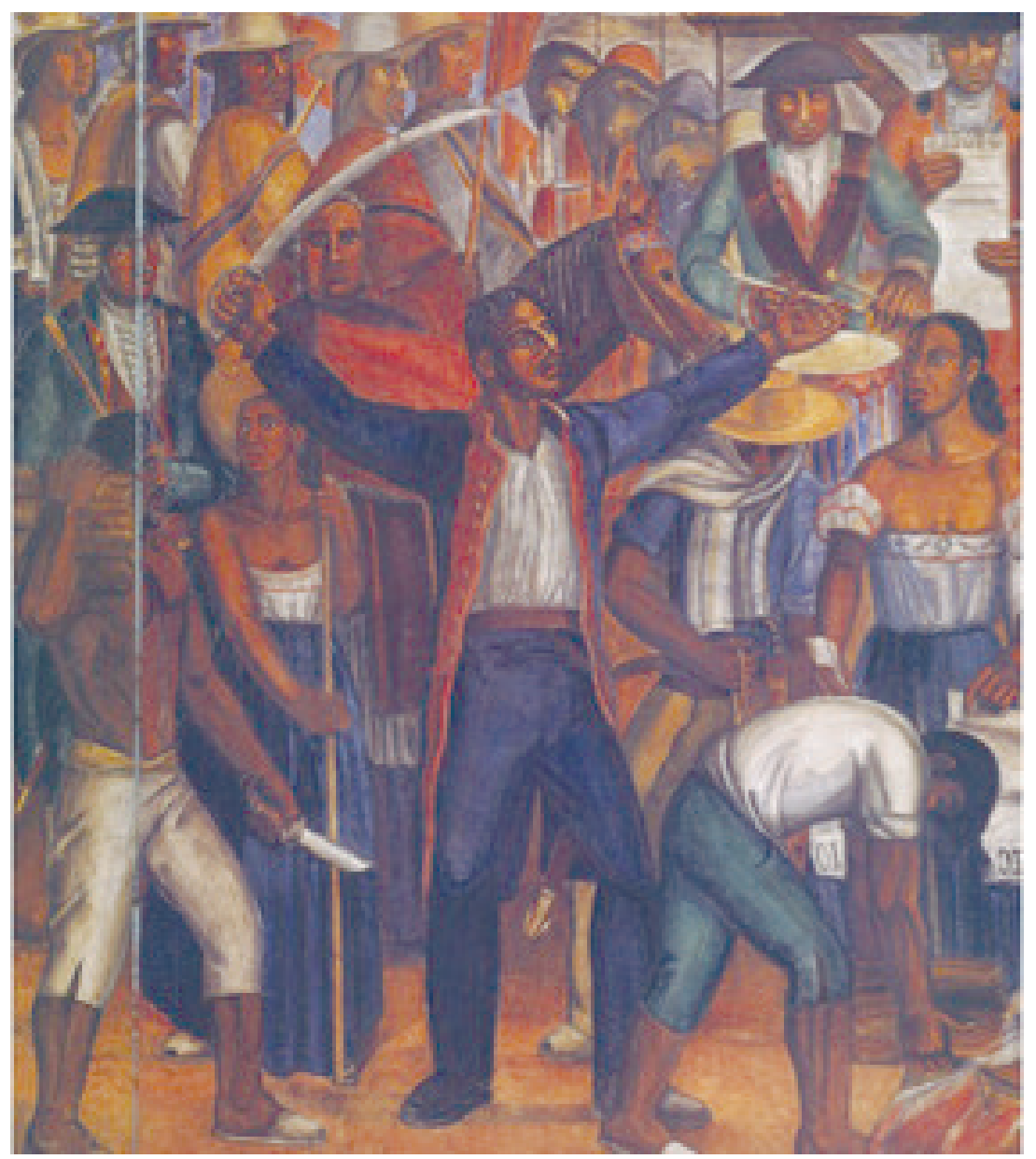

Image 9

Ignacio Gómez Jaramillo

La insurrección de los comuneros, 1938.

Fresco

Images taken from the book Ignacio Gomez Jaramillo. Bogotá: Villegas

Editores, 2003 
The Mexican Assimilation: Colombia in the 1930s - The case of Ignacio Gómez Jaramillo

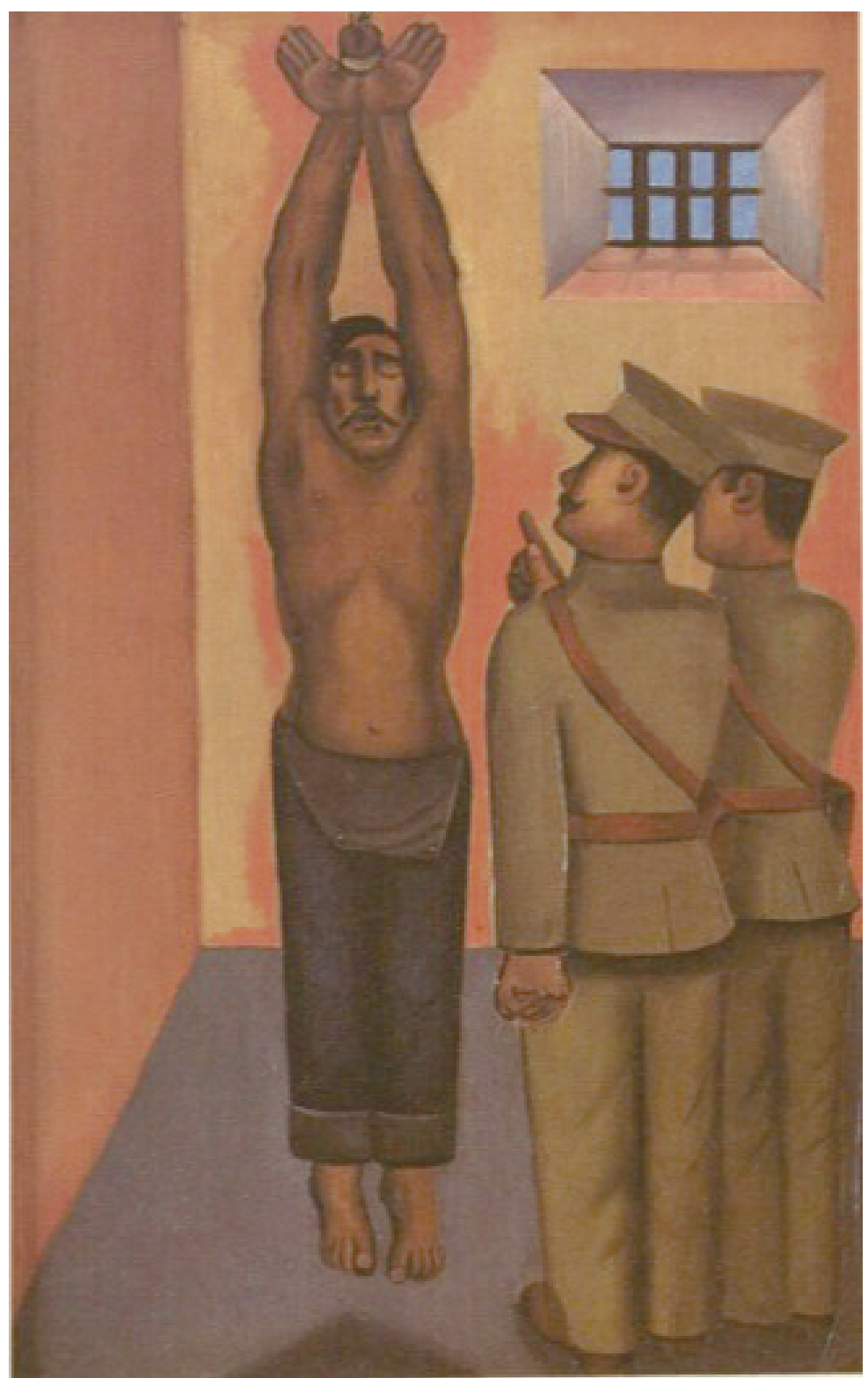

Image 10. David Alfaro Siqueiros

El Tormento, 1930.

Oil on canvas

$60.2 \times 40.2 \mathrm{~cm}$

Collection of Mauricio Fernández.

Photo taken from the book Portrait of a Decade 1930 -1940

México, D.F.: Instituto Nacional de Bellas Artes,1997. 

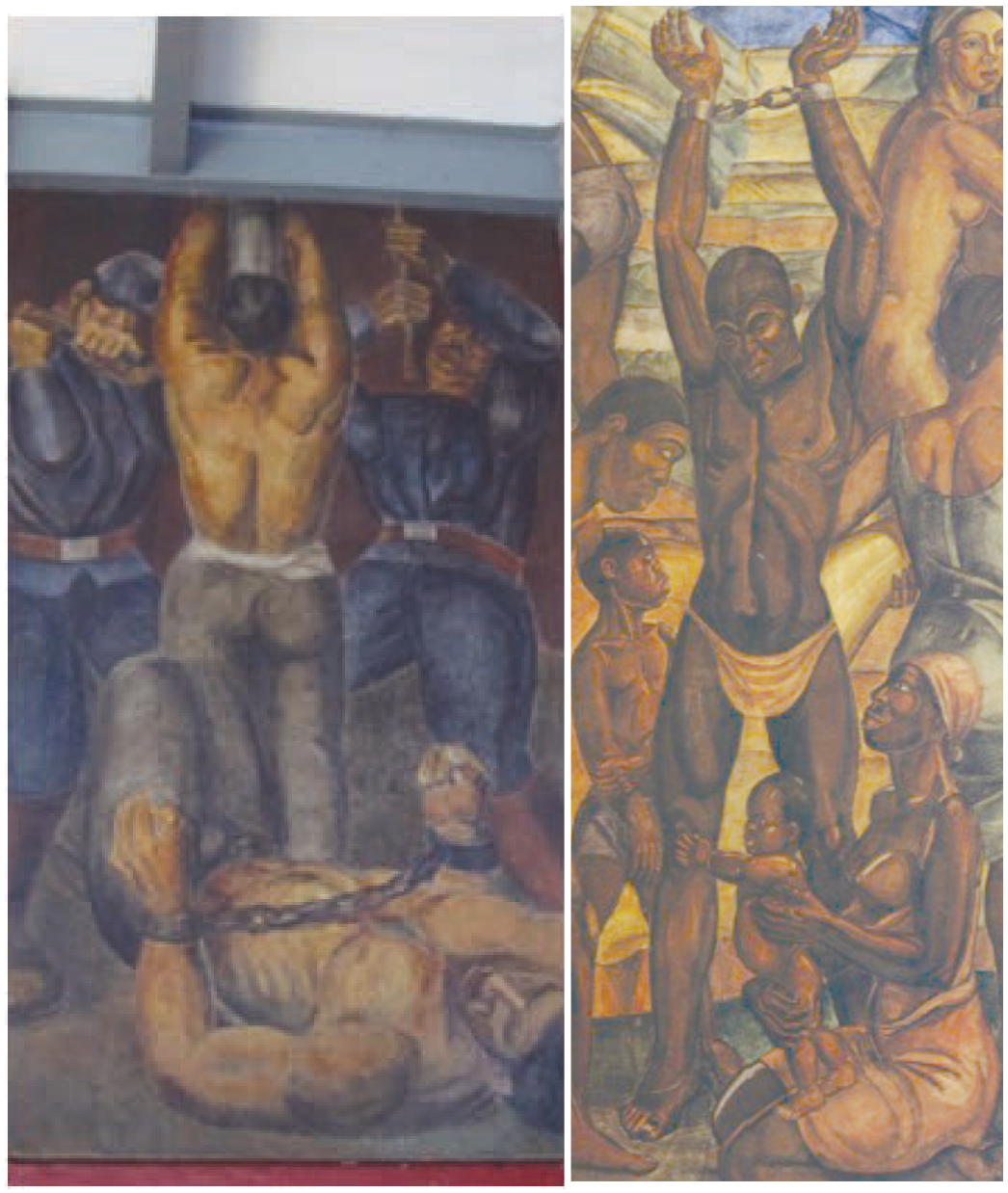

Fragments from l: La represión de los obreros and r: La liberación de los esclavos by Gómez Jaramillo

The second mural at the National Capitol, La Insurreción de los Comuneros, depicts another passage of Colombia's history. In 1781, a group of peasants and criollos in the department of Santander rebelled against the viceroyalty. A renewal of a tax on sales to the "Armada de Barbolento" by the visiting regent Juan Francisco Gutiérrez de Piñeres dramatically affected the producers of cotton, a product that made up a large 
part of the Armada's order. In the mural, the regent appears in upper right, wearing a red uniform, standing next to a man playing the drum, while announcing the edict. A group of criollos, led by Juan Francisco Berbeo, Salvador Plata, Antonio Monsalve and Francisco Rosillo, constituted a board named $\mathrm{El}$ Común, from which the name Los Comuneros derives. One of the Comuneros leaders stands in the foreground of the picture with his arm raising a sword. The position of his body is challenging and suggests confrontation. During the uprising Manuela Beltrán, a peasant woman from the Santander area, broke the edict of the new taxation regimen, screaming the now famous words "Long live the king, death to the bad government," an episode also portrayed by Gómez Jaramillo. Both Manuela Beltrán and the other woman to the left of the picture are wearing the traditional peasant dresses of Santander. In the middle ground to the left, Gómez Jaramillo portrays the Spanish authorities and the viceroy Caballero y Góngora, while in the background the protestors march towards the right of the mural. The revolt, initially supported by the poor social classes, slowly began to have native and upper class followers as well. Approximately four thousand people marched towards Santa Fé, the capital city of the New Granada, protesting against the new law. The event ended with a sham negotiation with the government. The Viceroy, who was in Cartagena at the time of the concession, declared that the conciliation document - which favored the Comuneros - was signed under threat and was therefore invalid, thus reinstating the initial conditions. The Comuneros uprising is considered one of the most significant episodes from Colombian history, a key event leading up to the 1810 independence.

Gómez Jaramillo made two different watercolor sketches for this project, one highly detailed and one less complex (Image 11). The differences between the first sketch and the second are the insertion of the viceroy and the Spanish authorities into the composition, some changes in the characters clothing, and the inclusion of 
a series of red flags that the insurgents are carrying in the background. The similarities between the second sketch and the mural are remarkable, illustrated by the deletion of the guns that the woman on the left is holding and the gunpowder barrel that stands right below the comunero leader of the mural. The removal of "modern" guns gives a more historical character to the mural as does the disempowerment of the women, who in the final version, stand as submissive figures.
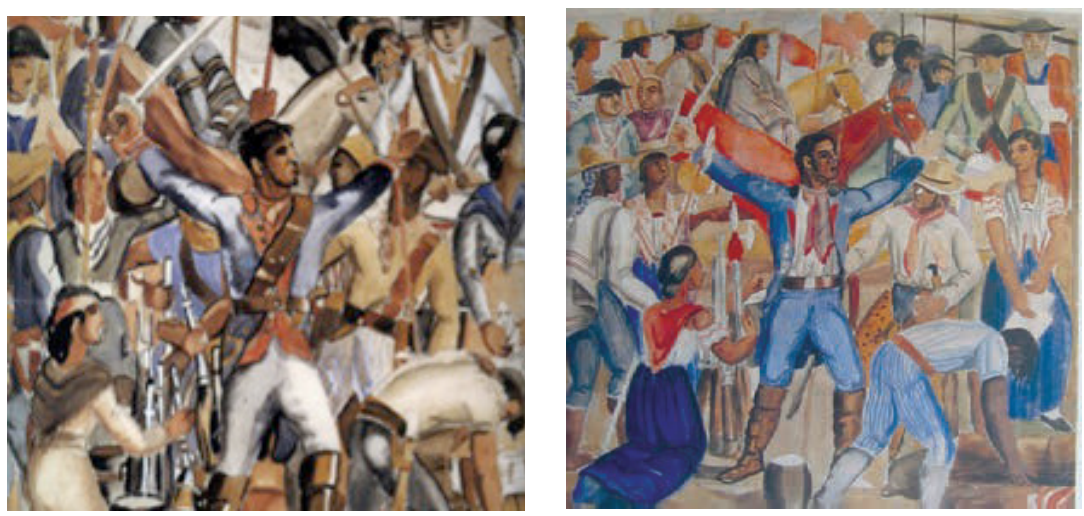

Image. 11

Ignacio Gómez Jaramillo

Sketches for La insurrección de los comuneros

Images taken from the book Ignacio Gomez Jaramillo. Bogotá: Villegas

Editores, 2003

Both La liberación de los Esclavos and La Insurreción de los Comuneros depict passages from Colombia's history and it is for this reason that many critics and scholars have considered them apolitical. For example, Cristina Lleras, in her article about art, politic and criticism in Colombia, stated that “(...) Gómez Jaramillo did not express political ideas; on the contrary, he tried to stay away from these debates." ${ }^{\prime 2} I$ would, however, argue the

20 Cristina Lleras. "Politización de la mirada estética: Colombia 1940 1952" in Revista Textos, no. 13 (2005): 54. 
The Mexican Assimilation: Colombia in the 1930s - The case of Ignacio Gómez Jaramillo

contrary, because even though Ignacio Gómez Jaramillo considered himself an artist not interested in propaganda art, the issues that the murals represent are political in the sense that the depicted passages were supported by liberals and opposed by conservatives. This was reflected in contemporary critical comments published in the press and the huge scandal that the murals generated, ultimately leading to their censure. A letter from a reader of El Tiempo —one of the most important newspapers in Colombia - referred to the murals as "indecent doodles" and to Ignacio Gómez Jaramillo's painting as "plebeian and ugly." ${ }^{21}$ Comments in magazines like Estampa and in newspapers like La Razón, El Espectador, and El Liberal generated a similar polemic, some supporting and others criticizing the artworks. In September of 1939, the council of Bogotá approved the elimination and substitution of the murals, arguing that "the paintings are truly monstrous and suffer from faults inseparable from the very principles of pictorial art. They contribute to the public's artistic simplification and from that point of view they are inappropriate for the culture itself." 22

As art historian Eduardo Serrano pointed out, the title "Un Nuevo fracaso del arte marxista" ("A new failure of Marxist art") of the article in which the covering of the murals was made public, "is sufficiently explicit regarding the political identification of the paintings with a radical political position." 23 Additionally, after being involved in a highly political group such as the LEAR in Mexico, it is unlikely that Gómez Jaramillo's social and political interests abruptly disappeared, especially in the context of a strong battle between the most important political parties in Colombia. More over, the opportunity to leave his legacy in one of the most

\footnotetext{
${ }_{21}$ A reader. "Sobre los frescos" in El Tiempo. (January 9 1939): 4.

22 Ramón Rosales in Álvaro Medina.El arte Colombiano de los años 20 y 30. (Bogotá: Colcultura, 1995), 167.

${ }^{23}$ Eduardo Serrano. "Ignacio Gómez Jaramillo" in Anotaciones de un pintor. (Medellín: Ediciones Autores Antioqueños, 1987), 273.
} 
significant buildings of the country was unique, and he performed it in an ingenious manner by depicting passages of Colombia's history, specifically those that evoke "revolutions" achieved by el pueblo. The murals were not only done in an expressionistic style that conservatives like senator Laureano Gómez rejected, but also contrasted strongly with the neoclassical architecture of the National Palace's building. In his famous article "El Expresionismo como sintoma de pereza e inhabilidad en el arte" ("Expressionism as a symptom of laziness and inability in the arts") Laureano Gómez referenced the "the bawdy farce of Expressionism [that] has infected America" and referred to muralism both in Mexico and Colombia as a

[...] false and disingenuous pretext of seeking greater intensity of expression... to hide the ignorance of drawing, the lack of talent for composition, poverty of imagination, lack of technical knowledge, lack of academic preparation, research and personal exercise of the hand's mastery and the eye's subconscious insight. ${ }^{24}$

In 1940 Gómez Jaramillo won the first prize in the Salón Nacional de Artistas with the painting Madre del Pintor (1940) that, although not related to the Capitol murals, sparked a new scandal in the press. Both the comments that appeared after the completion of the murals and those published after the prize was awarded, signal the clear subordination of aesthetic discourse to the political sphere. As art historian Cristina Lleras has asserted, it seemed that in Colombia the arts were under the oppression of a government, in which the form became propaganda directed by the interests of the party. ${ }^{25}$

$24 \quad$ Laureano Gómez. "El expresionismo como síntoma de pereza e inhanilidad en el arte" in Alvaro Medina, Procesos del arte en Colombia. (Bogotá: Instituto Colombiano de Cultura, 1978)

25 Cristina Lleras. "Politización de la mirada estética: Colombia 1940 1952" in Revista Textos, no. 13 (2005): 55. 
The Mexican Assimilation: Colombia in the 1930s - The case of Ignacio Gómez Jaramillo

It took ten years for the murals to be removed. In 1948, the conservative government of Mariano Ospina Pérez, Laureano Gómez ${ }^{26}$ ordered to cover the frescos -including the one at the Teatro Colón- "on the occasion of the celebration in Bogotá of the Ninth Pan American Conference, where the Capitol would be the main stage." ${ }^{27}$ Eduardo Serrano asserted that the murals were covered with paper rolled up in copper, guadua ${ }^{28}$ and cement. Years later, in 1959, a group of students from the fine arts academy rediscovered the frescos and restored them under the supervision of Ignacio Gómez Jaramillo himself. ${ }^{29}$

During the 1930s the interest of the liberal government in supporting public art was related to many issues ranging from education and culture to politics, as a way to express resistance against the opposition. Gómez Jaramillo's trip to Mexico became part of a larger intricate political agenda that López Pumarejo's government was enacting. In Colombia, public art was initially appropriated and understood as a means for the dissemination of socialist values as well as an instrument that promulgated progress and change in a nation desperately in need of a sense of identity. This was evident with the commission of National Capitol murals, which, in light of Gómez Jaramillo's trip to Mexico,

\footnotetext{
${ }^{26}$ Laureano Gómez (1889-1965) was a conservative president of Colombia who governed from 1950 to 1953 . Before becoming president he was senator, president of the conservative party and ran the newspaper El Siglo, in which many of the critics-some even written by him-against the work of the Americanist artists were published. He was an openly supporter of fascism. One of his most famous articles "El Expresionismo como síntoma de pereza e inhabilidad en el arte" criticizes the work of the Mexican Diego Rivera and Colombian Pedro Nel Gómez.

27 Eduardo Serrano. "Ignacio Gómez Jaramillo" in Anotaciones de un pintor (Medellín: Ediciones Autores Antioqueños), 273.

${ }^{28}$ Guadua is a South American type of Bamboo used mostly for construction proposes.

29 Eduardo Serrano. "Ignacio Gómez Jaramillo...273.
} 
acquire political implications. It is hard to imagine that an artist involved in an openly leftist organization such as the LEAR, would abandon his convictions just months after leaving the country that boosted his artistic career. Although the National Capitol murals depict historical passages of Colombia's history, these also align with the liberal's interest acquiring this way a political intention that today might not seem evident but when in looked in their original context becomes clear.

Public art in Colombia became more of asecret political tool than a truly progressive instrument. In spite of the efforts by the liberal government to promote muralism and other types of public art, like the escuelas de pintura al aire libre, that same government was responsible for the failure of the project. Besides the murals discussed in this paper and the eleven frescos for the Consejo de Medellín that Pedro Nel Gómez painted in 1935, no other public art was commissioned during that time. Yet these unique efforts helped to consolidate a modern attitude towards the arts and, especially, to encourage a new critical thinking about America within the Americas.

\section{Archive sources}

A reader. "Sobre los frescos", El Tiempo. January 91939.

"Diego Rivera decorará el Centro Revolución", El Nacional: Diario popular (Mexico City) January 11, 1935

"Pinturas en las escuelas", El Nacional: Diario popular (Mexico City), December 24, 1935.

\section{Bibliography}

Acevedo, Esther. "Del Muralismo al Neomuralismmo en la obra de Raúl Anguiano (1936-2005)" in Raúl Anguino 1936- 
The Mexican Assimilation: Colombia in the 1930s - The case of Ignacio Gómez Jaramillo

2005. Mexico DF: Antiguo Coloegio de San Idelfonso and Dirección General de Publicaciones del Conalcuta, 2006.

Anguiano, Raúl. Anguiano por Anguiano. Pachuca, México: Universidad Autónoma del Estado de Hidalgo, 1997.

Ardila Duarte, Benjamín. "Alfonso López Pumarejo y la Revolución en Marcha" Revista Credencial Historia. 192 (2005).

Barbosa, Ana Mae. "The Escuelas de Pintura al Aire Libre in Mexico: Freedom, Form, and Culture" Studies in Art Education.Vol. 42, No. 4 (Summer, 2001).

Beltrán Trenado, Luz Angélica. "Centro Escolar Revolución: la construcción de un espacio escolar" (Masters Thesis, UNAM, 2009).

Bermúdez, Egberto et al. El Nacionalismo en el arte. Bogotá: Universidad Nacional de Colombia, Facultad de Arte, Instituto de Investigaciones Estéticas: Centro Hábitat de Colombia, 1984.

Bermúdez, Egberto et al. Memoria: Instituto de investigaciones estéticas. Bogotá: Universidad Nacional de Colombia, Facultad de Artes, Instituto de Investigaciones Estéticas, 2010.

Borda, Juan Gustavo. Ignacio Gómez Jaramillo. Bogotá: Villegas, 2003.

Cajigas R., María de los Angeles. Raúl Anguiano: uno de los cuatro ases del muralismo mexicano. México: Edamex, 1995.

Cárdenas, Jorge. 10 Maestros antioqueños. Medellín: Cámara de Comercio, 1981.

Comisarenco, Dina. "Aurora Reyes's 'Ataque a la maestra rural"' in Woman's Art Journal Vol. 26 No. 2

Frente a Frente. "Balance de la LEAR." Frente a frente: Órgano Central de la Liga de Escritores y Artistas Revolucionarios (México City), no.7 (January 1937): 10. 
Frente a Frente. "Resumen del Congreso Nacional de Escritores y Artistas convocado por la LEAR." Frente a frente: Órgano central de la liga de escritores y artistas revolucionarios. (México City), no. 8 (March 1937): 22-24.

Frente a Frente. "Síntesis de los principios declarativos de la LEAR." Frente a Frente (México City), no. 1 (November 1934): 3.

Fuentes Rojas, Elizabeth. "Liga de escritores y artistas revolucionarios: una producción artística comprometida." (PhD Dissertation, UNAM, 1995).

García, Julio César. Liberación de los esclavos. Medellín: Imp. Departamental, 1956.

Geis, Terri. "The Struggles of modernizing Mexico and the mural of Aurora Reyes at the Centro Escolar Revolución", Women's Contribution to Visual Culture, 1918 - 1939. Ed. Karen Brown. Aldershot, England; Burlington, VT: Ashgate Pub, 2008.

Goldman, Shifra M. Dimensions of the Americas: art and social change in Latin America and the United States. Chicago: University of Chicago Press, 1994.

Gómez, Carlos Jiménez. Notas y ensayos: un intento de penetración al fenómeno Antioqueño. Medellín: Aquirre, 1967.

González, Beatriz. "Ignacio Gómez Jaramillo. El azaroso destino del arte Colombiano" in Arte en Colombia, No. 38 (1988): 74-78

Ignacio Gómez Jaramillo. Anotaciones de un pintor. Medellín: Ediciones Autores Antioqueños, 1987.

Lleras, Cristina. "Politización de la mirada estética: Colombia 1940 - 1952”, Revista Textos, No. 13 (2005).

Lozada, Lucía Santa Ana. "Arquitectura escolar en México". Bitácora Arquitectura, No. 17 (2007). pp 70-75. 
The Mexican Assimilation: Colombia in the 1930s - The case of Ignacio Gómez Jaramillo

Martínez, Pablo L. Plan General de Organización y funcionamiento de los talleres del Centro Escolar "Revolución. México D.F. Imp. del C. E. "Revolución”, 1936.

Medina, Álvaro. El arte Colombiano de los años 20 y 30. Bogotá: Colcultura, 1995.

Medina, Álvaro. Procesos del arte en Colombia. Bogotá: Instituto Colombiano de Cultura, 1978.

Owen, Gilberto. El Arte en Colombia: Ignacio Gómez Jaramillo. Bogotá: Librería Suramérica, 1944.

Pan American Union. Ignacio Gómez Jaramillo. Washington, D.C.: Pan American Union, 1956.

Pini, Ivonne. En busca de lo propio. Inicios de la modernidad en el arte de Cuba, México, Uruguay y Colombia.1920-1930. Bogota: Universidad Nacional, 2000.

Quintanilla, Lourdes. Liga de Escritores y Artistas Revolucionarios (LEAR). México, D.F.: Centro de Estudios Latinoamericanos, Facultad de Ciencias Políticas y Sociales, UNAM, 1980.

Valencia, César Julio. Liberación de los esclavos: Fresco mural ejecutado por Ignacio Gómez Jaramillo. Movimiento antiesclavista. Medellín: Gobernación de Antioquia, 1956.

Vela, Arqueles. "La exposición de artes plásticas de la LEAR." Frente a Frente: Órgano Central de la Liga de Escritores y Artistas Revolucionarios (Mexico City), No. 4 (July 1936): 2021.

Zalamea, Jorge. Nueve Artistas Colombianos. Bogotá: Litografía Colombia, 1941. 